\title{
Childhood Non-T Non-B Acute Lymphoblastic Leukemia
}

National Cancer Institute

\section{Source}

National Cancer Institute. Childhood Non-T Non-B Acute Lymphoblastic Leukemia. NCI

Thesaurus. Code C114576.

Non-T non-B acute lymphoblastic leukemia that occurs during childhood. 